\title{
Exploration of Necessity of Establishing Environment Personality Right and Its Constraints
}

\author{
Shu'e Fu \\ Inner Mongolia University for the Nationalities, Tongliao 028000, China
}

\begin{abstract}
Keywords: Environment personality right; Necessity; Constraint
\end{abstract}
\begin{abstract}
Under the background of environmental crisis, people's environment personality benefit is greatly damaged. So, establishing environment personality right becomes an issue concerned by the legal circle. Beyond all doubt, it is necessary to establish environment personality right, but it is required to fully consider the constraints to establish environment personality right, protect people's environment personality right and solve environmental crisis from legal perspective. This paper mainly explores the necessity and constraints of establishing environment personality right and provides certain reference for establishing environment personality right.
\end{abstract}

\section{Introduction}

Different people have diverse understanding of environment personality right. So far, there has been no an exact definition, but most people consider environment personality right owns spirituality. Environment personality as a spirit right greatly promotes satisfaction of people's spiritual needs. However, because such right has spirituality and its connotation is not explicit, the relevant legislation does not regard environment personality as a right of personality in laws in China. As environmental crisis arrives, people's life health is threatened. The significance of environment is increasingly concerned. Hence, establishing environment personality right also becomes an issue to be solved in legislation and judicial circles. Finding out the constraints has important functions for establishing environment personality right.

\section{Overview of environment personality right}

With rapid economic development, people's living standards improve and their requirements for spiritual life also become increasing high. Meanwhile, comfortable living environment also gradually becomes a fundamental need. Thus, it is necessary to enhance environmental protection. Environment right was born at the right moment. For China, the issue about environment right started to be discussed in 1980s. Besides, environment right debate was carried out. Relatively famous scholars include Prof. Lv Zhongmei and Mr. Cai Shouqiu etc. In 1990s, Prof. Lv considers there is short of environmental protection laws and that environment right should be protected as a right. Defects of environmental protection in legal field mainly include the following aspects: 1) an obstructive factor in environmental protection is property right system; 2) personality right system lacks environmental protection problems. Environmental protection is actually closely related to people's life health. Environment right serves as an important right in environmental protection. It is very important to establish environment right in laws. Environment personality right is a right that every citizen should enjoy and also a development trend of China's future legislation and juridical practice.

Environment personality mainly reflects interpersonal relationship in the relation between men and nature. Environment personality is a subjective factor in the relationship. The main contents include the following: environment personality embodies the position of human in nature. In other words, when people get along with nature, they should gain comfortable living environment from natural environment. This reflects human dignity. In addition, environment personality also embodies social subject position and inherits personality theory. It is also a right everyone should enjoy in social life. Hence, if living environment is damaged, this means human dignity is violated. 
Meanwhile, human natural position and social status are shaken. So, environment personality is an important constituent part of personality. Everyone should enjoy environment personality benefit. Everyone has the right to enjoy comfortable environment. Thus, it is required to protect it legally. Environment personality is the expansion of personality and a very important aspect which should be valued.

\section{Necessity of establishing environment personality right}

\section{Establishment of environment personality can settle the difficult situation where} environmental litigation plaintiff is not qualified to prosecute

Many great water contamination accidents impose great damages to human body and life as well as comfortable living environment rights and interests people should enjoy. But when proceedings are instituted against related manufacturing contamination methods, who is qualified to be the lawsuit? And who has the right to prosecute? This seems to be very confused. Some cases end up with nothing definite due to the doubt of qualification of the plaintiff. The court also refuses to accept such cases. Such cases are seen everywhere in China. China's laws do not explicitly provide prosecution qualification of the plaintiff. Thus, a large number of environmental tort cases cannot be put on records, leading to numerous difficulties of such cases.

China's environmental protection act provides all units and individuals have the obligation of protecting environment and have the right to report and accuse units and individuals damaging environment. Such provision just stipulates people are entitled to accuse environmental disruption, but fails to explicitly stipulate the quantification of the plaintiff. Meanwhile, administrative litigation laws also provide that citizens may take actions for the behaviors violating legal interest. Such provision points out that the precondition of taking action is administrative act and violation. But for environmental lawsuit, there is no explicit provision in China's law. Moreover, in terms of civil action, the law also stipulates the plaintiff must have direct relations with the case. Thus, in many environment accidents, people have no prosecution qualification. This gives rise to difficulties in putting on records of such cases. The establishment of environment personality right can settle this problem, relieve this plight and supplement China's legal defects.

\section{Establishment of environment personality right is the perfection of personality right}

Personality embodies the subjectivity of human beings and also a basic element one must own. In the traditional sense, personality may be understood as the sum of temperament, ability and character, or moral trait, or the right people enjoy and obligation people must perform. These understandings reflect human social attribute and set forth interpersonal relationship, but neglect the relationship between human and nature. Environment personality reflects natural attribute of human beings. Human status in nature also embodies human dignity. If human living environment is damaged, this means human personality is infringed. Therefore, establishment of environment personality reflects natural quality. Obviously, personality right is not perfect enough. The relation between man and nature is relevant. Hence, human being not just owns social attribute, but also has natural quality. Human dominant position contains human social attribute and natural quality. Both cannot be violated. Therefore, establishment of environment personality right supplements personality right and plays the role of perfecting personality right.

\section{Establishment of environment personality right can supplement civil law}

The civil law also provides environmental protection, but is only limited to maintaining people's health right ad life right. This is obviously not sufficient enough. First of all, health right ad life right which are provided in the civil law fail to reflect environment personality right. In other words, when people's health right and life right are infringed, they have litigation right. Sometimes, environment personality right does not contain damage to human life health. It more reflects the damage to human spirit. People cannot gain conformable living environment. This infringes human spiritual rights and interests and also reflects violation of environment personality right. Secondly, neighboring relation system established in civil law limits environment personality right. Environmental tort does not reflect neighboring relation in actual life, such as air pollution and noise pollution. Civil neighboring 
relation cannot serve as the basis to protect environment personality right. Finally, tort liability law has limitations. Tort liability law stipulates that in case of damage caused by environmental pollution, manufacturers should undertake liability for tort. At the same time, if a dispute results from environmental pollution, the contamination party and damage have no causal relationship. As per laws and provisions, the contamination party may not bear the liability. It can be seen from this provision that if the contamination party is required to undertake the liability for tort, there must be concrete damage. But, since environmental damage cannot be reflected in a short time, environment personality right cannot be protected in time. Environment personality right reflects people's spiritual right and interest. A favorable living environment will make people's mentality and mood relieved. This also reflects people's basic personality right. Thus, it is necessary to establish environment personality right.

\section{Constraints of establishing environment personality right}

\section{Theoretical basis}

For environment personality right, there are disputes for a long time. The main contents for disputes include the following: whether environment personality right is scientific; fuzziness of environment personality right and the position in environment personality right system. Thus, theoretical basis hinders establishment of environment personality right.

Firstly, environmental crisis results in the difficulty in establishing environment personality right. Most scholars in educational circle hope to create environment personality right to protect environment personality benefit. However, whether environment personality right is scientific? This still has disputes in educational circle. Some scholars believe environment personality right does not own scientificity and consider such idea is arbitrary addition of personality right. They propose that environment personality right confuses environment personality benefit and environment personality right and violates the needs and hope. It thus can be seen that once the theory without scientificity is created, the theory will not be established.

Secondly, the major content of environment personality right is environment personality benefit. Environment personality benefit is a right with spirituality characteristic. It aims to protect people, make people live in a comfortable environment and bring certain sense of joy and spiritual interests. So, the measurement standard has certain fuzziness. The fuzziness of right object forms certain influence on boundary problem of environment personality right. If the boundary is not defined, creation of environment personality right will be seriously influenced.

Finally, even if personality right has certain development nature and openness and environment personality right can be added in personality right system, environment personality right will not be added in personality system of civil law. However, most scholars still approve that environment personality right is added to personality right of civil law after researches. Similarly, some scholars hold that environment personality right should not be defined in personality right. In this way, certain conflicts will form. In China, we are not anxious to establish this theory in current stage. So, the theory hinders the status of environment personality right in laws to some extent.

\section{Juridical practice}

In juridical practice, the constraint is that litigation law protecting environment personality right has no strong credibility. This is also a major factor. Since the new right is found in juridical practice, it gradually becomes a real power.

Firstly, there are problems for legal support. Legal support has no certain procedure. Meanwhile, other departments are not coordinated. Thus, it is of no worth to confirm new rights. There is no real power. Environment personality is the result of materialization of environment right and owns certain protection functions. Hence, to protect environment personality right, it is necessary to mutually cooperate with relevant departments and procedures. Besides, environment personality right is a private right for public welfare and can be achieved by depending in procedure protection. Because the need of environmental nonprofit litigation should be lower than environment litigation, with 
social development, environmental nonprofit litigation gradually receives attention to supplement economic capability imbalance in environmental nonprofit litigation.

Secondly, certain problems exist in court credibility. In juridical practice, the problems existing in court credibility cause that most environmental lawsuits are not handled by courts. This does not mean only courts can settle problems. Once the problems are handled through other means, certain obstruction will form for achieving citizens' legal rights, especially for confirmation of new rights.

Finally, annual occurrence rate of environmental problems presents a rising trend, but the cases where environmental problems are handled through court lawsuit are few. The rough cause is that prosecution qualification is restricted. Most legal practices in China will be solved finally through governmental administrative methods. Thus, it can be seen that under such case, new environment personality right cannot be established by use of juridical practice.

\section{No successful oversea experiences which can be referred to in legislation}

In current stage, in foreign legislations, some countries also establish environment personality right. After all, there are only a minority of countries. According to the survey, only Ukraine establishes environment personality right. Ukraine provides environment personality right in civil code. In other words, people enjoy the right to survive in a healthy and safe environment. This provides and sets forth environment personality right in detail. It is different from life health right. Environment personality right is achieved through right of claim. Both developed countries and other countries which attach importance to environmental protection fail to explicitly stipulate environment personality right and even do not involve environment personality right. Many countries do not admit environment personality right. This gives rise to difficulties in establishing environment personality right. Since there are successful experiences, there is no basis in legislation. Even if China's legal circle has realized the necessity of environment personality right, the lack of practical experience becomes a constraint to establish environment personality right.

China has no high legal consciousness, and environmental protection becomes a weak link

Since Chinese citizens generally have no high legal consciousness and they have too many requirements for their own rights, environment personality right is not accepted by citizens. Environmental protection is both a right and an obligation for every citizen. But in real life, folk environmental protection organizations are few. The disputes about environmental protection cannot be solved, which triggers a great obstruction for establishing environment personality right.

\section{Conclusions}

As environmental protection is extremely urgent, it is necessary to establish personality right. It is also a necessary means to settle environmental crisis. For China, establishment of environment personality right is the key to supplementing China's related laws. It is required to carefully analyze constraints, adopt corresponding schemes in allusion to constraints and gradually establish environment personality right.

\section{References}

[1] Hu Weiping, Qiu Ting, legislation confirmation of environment personality right and bearing tortuous liability. Journal of East China Jiaotong University, 2013(1)

[2] Han Yingmei, Song Zhenyu, Exploration of environment personality right and its civil law protection. Huazhang, 2014(15)

[3] Hu Weiping, Legislation confirmation of new personality right. Legal Forum, 2011,26(6)

[4] Liu Jinping, Exploration of civil law protection mode of environment personality right. Fa Zhi Bo Lan, 2014(5)

[5] Jia Guohua, Zhang Jin, Analysis of environment personality right. Market Modernization, 2012(29) 
